\title{
Antimicrobial Susceptibility and Biochemical Characteristics of Streptococcus suis Isolated from Diseased Pigs in Gyeongbuk Province
}

\author{
Seong-kyoon Choi, Seong-guk Kim, Young-hoan Kim, Jeong-hye Choi, Min-hee Jo and Gil-jae Cho ${ }^{1 *}$ \\ Gyeongbuk Veterinary Service Laboratory, Daegu 702-210, Korea \\ ${ }^{1}$ College of Veterinary Medicine, Kyungpook National University, Daegu 702-701, Korea
}

Received August 18, 2010 /Accepted October 4, 2010

\begin{abstract}
Streptococcus suis is a worldwide pathogen of a variety of porcine infection and has also been described as a pathogen for humans. We studied biochemical characteristics, antimicrobial susceptibility, and identification of polymerase chain reaction (PCR) of $S$. suis isolated from diseased pigs in Gyeongbuk province from 2004 to 2009. Sixty-one isolates were identified as S. suis by biochemical characteristics and PCR from 40 farms. The biochemical characteristics of $S$. suis isolates were production of VP-negative, hippurate, esculin, and arginine decarboxylase-positive, and fermentation of carbohydrate was variable lactose, trehalose, inulin, and raffinose, which was typeable 11 phenotype. In an antimicrobial susceptibility test, the majority of isolates were highly susceptible to amoxicillin/clavulanic acid, ampicillin, cephalothin, cefoperazone and florfenicol, while being highly resistant to streptomycin, kanamycin, amikacin, neomycin, erythromycin, clindamycin, and tetracycline. The isolates were divided into 11 phenotypes of biochemistry. By using PCR, the 16S-rRNA gene DNA fragment was detected at $304 \mathrm{bp}$ from all of isolates. These results may provide the basic information needed to establish strategies for the prevention of $S$. suis infection in pigs.
\end{abstract}

Key words : Streptococcus suis., antimicrobial susceptibility, biochemical characteristics, PCR

\section{서 론}

Streptococcus suis (S. suis)는 Gram 양성의 연쇄구균으로 면 양혈액 $5 \%$ 첨가배지에서 주로 $a-$ 용혈을 일으키고 상부호흡기 관(특히 편도 및 비강), 생식기계 및 소화기계통에 상재하며 돼지뿐만 아니라 대부분의 동물에 감염되어 질병을 일으킨다. 또한 사람에서는 도축장, 양돈장, 식육점 등의 종사자와 수의 사에게 주로 감염되는 인수공통의 전염병이다[2,14,29,43]. 대 부분의 S. suis는 $6.5 \% \mathrm{NaCl}$ 첨가배지에서는 성장하지 않으며, Voges-Proskauer (VP) test 음성을 나타내고, trehalose와 salicin 첨가 배지에서 산을 생성한다[15]. 1951년, 네덜란드의 Jansen과 Van Dorssen [20]에 의해 S. suis 감염이 보고된 이후 1956년, de Moor [6]가 생화학적 및 혈청학적으로 새로운 a-용 혈형성 연쇄구균군을 보고하여 Lansfield group D에 속하는 새로운 연쇄구균으로 제안된 이후 현재까지 35종의 협막혈청 형이 알려져 있다[17,18]. 대부분의 협막형 표준균주는 인체분 리유래 14형, 건강한 돼지에서 분리한 $17,18,19$, 21형, 그리고 이환된 송아지에서 분리한 31형, 이환된 양에서 분리한 33형 을 제외하고 대부분 환돈에서 분리되었다[9,17]. S. suis의 질병 유발인자로는 균외막을 형성하는 $136 \mathrm{kDa}$ 크기의 muramidase released protein (MRP), $110 \mathrm{kDa}$ 의 extracellular

\footnotetext{
*Corresponding author

Tel : +82-53-950-5978, Fax : +82-53-950-5955

E-mail : Chogj@knu.ac.kr
}

protein factor $(\mathrm{EF})$, 적혈구를 용혈시키는 hemolysin인자, capsule 등이 알려져 있다[11,12,46]. 환돈에서 분리된 S. suis의 경우 병원성인자인 MRP와 $\mathrm{EF}$ 인자를 대부분 가지고 있으며 건강한 자돈 분리주는 대부분 $\mathrm{MRP}$ 와 $\mathrm{EF}$ 인자를 유전자 내 포 함하지 않고 있는 것으로 알려져 있다[47].

돼지에서 S. suis는 주로 16주령 이하에서 발생하며[34] 아 급성의 경우 뚜렷한 임상증상 없이 폐사하거나 대부분 뇌막염 에 의한 운동실조, paddling, 안구진탕 등의 신경증상을 동반 한 전구증상을 나타내고[3] 관절염, 패혈증, 폐렴 등의 병변을 나타내며 드물게는 심내막염, 비염, 유산, 질염 등을 유발한다 [36,38]. S. suis는 사람 감염 예는 드물게 보고되고 있으나 돼지 와 유사한 증상을 나타내며 주로 뇌막염을 일으키고 패혈증과 심내막염을 동반하여 심각한 상황에 이르게 되며 북유럽과 동남아 지역에서 증례가 많이 보고되고 있다[7,23].

돼지의 경우 35형의 협막혈청형 중에서 질병발생의 양상에 따라 분리균주를 대상으로 조사한 결과 2형의 경우 이유자돈 에서 패혈증과 뇌막염을 주로 일으키는 것으로 조사되었고 [49], 네덜란드에서 병변별로 폐렴, 뇌막염, 내심근염, 다발성장 막염의 유형을 조사한 결과 각각 $42 \%, 18 \%, 18 \%, 10 \%$ 의 비율 로 협막 2형이 분리되었으며[48], 일본의 경우 뇌막염과 폐렴 병변의 이환돈에서 각각 $38 \%$ 와 $33 \%$ 의 2 형 분리율을 보고한 바 있다[22]. 환돈에서 분리한 대부분의 S suis는 1 형에서 8형 사이의 제한적인 협막혈청형을 가지고 이중에서 2형이 가장 많은 것으로 연구자들에 의해 보고되고 있다 $[8,16,18,22,34]$. 국 
내에서도 도축 출하돈의 폐 병변과 건강한 자돈의 편도 등에 서 S. suis를 분리하여 혈청형을 조사한 바 있다 $[24,37,42,54]$.

S. suis는 새로운 혈청형이 지속적으로 추가되었고 혈청형 별 생화학적 특성에 다소 차이가 있어 분리주의 동정에 어려 움이 있다. 건강한 돼지에서도 정상적으로 존재하므로 분리주 를 대상으로 생화학적 성상검사의 지표를 제시하여 동정에 이용하고 있으며[44] 상용화된 세균동정킷트를 이용한 방법도 많이 이용되고 있다[19,39]. 질병발생의 역학상황을 판단하기 위해 병원성인자의 확인과 더불어 PFGE (Pulsed Field Gel Electrophresis), ribotyping 등의 유전학적 분석방법을 동원하 여 균의 유전학적 특성을 조사하기도 한다[28,40]. 최근에 polymerase chain reaction $(\mathrm{PCR})$ 기법을 이용하여 균의 동정과 혈청형별을 위한 연구가 많이 진행되고 있다[21,24,27,41,50].

S. suis는 뇌막염 등의 질병발생 시 치료적인 항균제 처치가 곤란하나 기회감염균으로 체내에 상재되어 있는 균에 대한 예방적인 처치나 호흡기발생 시 처치를 목적으로 감수성 항균 제를 사용하고 있으며 항균제에 대한 내성양상을 관찰하기위 해 지속적인 균분리 및 항균제 감수성 시험을 실시하고 있다 $[1,26,32,53,55]$.

본 연구에서는 경북지방 양돈장에서 병성감정 의뢰된 돼지 가검물에서 분리한 S. suis를 대상으로 PCR에 의한 균의 동정, 생화학적 성상 및 항균제 감수성시험을 실시하고 그 결과를 보고하고자 한다.

\section{재료 및 방법}

\section{균의 분리}

2004년부터 2009년까지 경북지방 소재 양돈장에서 병성감 정 의뢰된 환돈을 부검하여 채취한 폐, 관절 및 뇌 등의 가검물 을 대상으로 면양혈액 $5 \%$ 첨가 혈액배지에서 $37^{\circ} \mathrm{C}, 18$ 시간 배양하였다. 다음 $a-$ 용혈을 일으키는 작은 집락을 분리하여 비동화 말혈청 $5 \%$ 을 첨가한 Tryptic soy agar (TSA, Difco, $\mathrm{USA})$ 에 계대하여 $37^{\circ} \mathrm{C}$, 18 시간 배양한 다음 $-70^{\circ} \mathrm{C}$ 에 냉동보관 하고 생화학적 성상, $\mathrm{PCR}$ 및 항균제 감수성시험 등 추가실험 을 실시하였다.

\section{생화학적 성상검사}

분리한 S. suis 의심균주에 대하여 상용화 세균 동정킷트 (API20-STREP, bioMeriux, France)를 이용하여 제조사의 지 침에 따라 생화학적 성상을 검사하였다.

\section{$\mathrm{PCR}$ 에 의한 균 동정}

균 동정을 위해 Marois 등[27]의 방법에 따라 S. suis의 특이 유전자부위인 16S-rRNA 부위의 primer (F: 5'-CAG TAT TTA CCG CAT GGT AGT TAT-3', R: 5'-GTA AGA TAC CGT CAA GTG AGA A-3')를 제작하여 PCR을 실시하였다. 분리주
의 PCR을 위해 genomic DNA 추출은 18 시간 순수분리하여 증균계대한 균주를 백금이로 1 획선 채취하여 멸균증류수 500 $\mathrm{\mu l}$ 첨가한 microtube에 접종하고 $90^{\circ} \mathrm{C}$ 에서 30 분간 중탕가열한 다음 $12,000 \mathrm{rpm}$ 에서 10 분간 원심분리하고 균체성분을 침전 시킨 후 상층액 $300 \mu \mathrm{l}$ 를 새로운 microtube에 옮겨 냉동보관 하면서 PCR을 위한 template DNA로 이용하였다. PCR은 Accu-Power ${ }^{\circledR}$ HL PCR premix [1U Taq DNA polymerase, $250 \mathrm{uM}$ each dNTP (dATP, dCTP, dGTP, dTTP), $10 \mathrm{mM}$ Tris-HCl (pH9.0), $40 \mathrm{mM} \mathrm{KCl}, 1.5 \mathrm{mM} \mathrm{MgCl}$, stabilizer and tracking dye, Bioneer $\left.{ }^{\circledR}\right]$ 에 template DNA $5 \mu$ 와 제작한 primer $1 \mu 1$ 를 첨가하여 T-gradient thermoblock (Germany, Biometra Co.)내에서 실시하였다. $\mathrm{PCR}$ 반응조건은 $94^{\circ} \mathrm{C}, 5$ 분 간 pre-denaturation시킨 다음, denaturation $\left(94^{\circ} \mathrm{C}, 30\right.$ 초), annealing $\left(60^{\circ} \mathrm{C}, 30\right.$ 초) 및 extension $\left(72^{\circ} \mathrm{C} 60\right.$ 초)의 과정을 30 회 반복 수행시키고 최종적으로 DNA extension을 $72^{\circ} \mathrm{C}$ 에서 5 분 간 실시하였다. $\mathrm{PCR}$ 이 끝난 후 증폭된 유전자 부위의 확인을 위해 ethidium bromide가 함유된 1.5\% agar gel (Bioneer, Korea)에 각 반응이 끝난 시료를 $8 \mu$ 씩 취하여 한천 사이에 점적한 후 $110 \mathrm{~V}, 30$ 분간 전기영동을 실시하고 자외선조사 하 에서 특정 위치의 DNA band를 확인하고 사진촬영을 실시하 였다. Molecular size marker는 $1 \mathrm{~kb} 100$ bp DNA ladder (Bioneer, Korea)를 사용하였다.

\section{항균제 감수성 시험}

항균제 감수성 시험은 Clinical Laboratory Standards Institute[4]의 기준에 따라 디스크 확산법(disc diffusion method)을 이용하여 다음과 같이 실시하였다. 먼저 분리주를 $5 \%$ 면양혈액첨가배지 $37^{\circ} \mathrm{C}, 18$ 시간 동안 배양한 후 멸균면봉 으로 집락을 채취하여 $5 \mathrm{ml}$ 멸균생리식염수에 균희석농도를 표준탁도(McFarland No. 0.5)로 희석하고 멸균면봉을 사용하 여 미리 준비한 $5 \%$ 면양혈액첨가배지에 균등하게 획선 도말 한 다음 항생제 $\operatorname{disc}$ 를 배지당 8 개를 접종하고 $37^{\circ} \mathrm{C}, 18$ 시간 배양한 후 disc 주위에 나타난 발육저지대를 caliper를 이용하 여 측정하였고, 항생제에 대한 감수성 결과는 disc 제조사에서 제시한 기준에 따랐다. 본 실험에 사용한 항균제는 BBL sensi-disc $\left(\mathrm{BD}^{\circledR}, \mathrm{USA}\right)$ 제품인 penicillin $(10 \mathrm{U})$, amoxycillin/Clavulanic acid (20/10 $\mu \mathrm{g})$, ampicillin (10 $\mu \mathrm{g})$, cephalothin $(30 \mu \mathrm{g})$, cefoperazone $(75 \mu \mathrm{g})$, cefepime $(30 \mu \mathrm{g})$, kanamycin $(30 \mu \mathrm{g})$, gentamicin $(10 \mu \mathrm{g})$, amikacin $(30 \mu \mathrm{g})$, neomycin $(30 \mu g)$, streptomycin $(10 \mu g)$, norfloxacin $(10 \mu g)$, erythromycin $(15 \mu \mathrm{g})$, clindamycin $(2 \mu \mathrm{g})$, ciprofloxacin $(5 \mu \mathrm{g})$, chloramphenicol $(30 \mu \mathrm{g})$, doxycycline $(30 \mu \mathrm{g})$, tetracycline $(30$ $\mu \mathrm{g})$, trimethoprim/sulfamethoxazole $(1.25 / 23.75 \mu \mathrm{g})$ 과 Oxoid $^{\circledR}(\mathrm{UK})$ 제품인 enrofloxacin $(5 \mu \mathrm{g})$, Ceftiofur $(30 \mu \mathrm{g})$, tilmicosin $(15 \mu \mathrm{g})$, spectinomycin $(100 \mu \mathrm{g})$, florfenicol $(30 \mu \mathrm{g})$ 등 24 종을 사용하였다. 


\section{결 과}

\section{균의 분리 및 동정}

2004년부터 2009년까지 경북지방 양돈장에서 병성감정 의 뢰된 돼지가검물에서 분리한 S. suis의 연도별 농장별 분리내 역은 Table 1과 같다. 40 개 양돈장에서 61주가 분리 동정되었 으며, 2005년과 2006년 분리주가 각각 22주 및 15주로 가장 많았다.

분리한 S. suis의 생화학적 성상을 검사한 결과는 Table 2와 같다. 분리주 61주 모두에서 pyruvate (VP) 음성이었고, hippurate (HIP), esculin (ESC), pyrrolidonyl 2-naphthylamide (PYRA), a-D-galactopyranoside (aGAL), $\beta$-D-glucuronate ( $\beta$ GUR), $\beta$-D-galactopyranoside ( $\beta G A L), ~ 2-n a p h t h y l$ phosphate (PAL), L-leucine-2-naphthylamide (LAP), Decarboxylation of arginine반응에서 모두 양성을 나타내었다. 당 분해능은 ribose, arabinose는 분해능이 없었으며, lactose는 모든 균주가 분해능이 있고 trehalose, inulin, raffinose, starch, glycogen은
균주마다 분해능에 차이를 나타내었으며, 전용동정프로그램 (apiweb, API 20 STREP ver 7.0)으로 동정한 결과 모두 S. suis 로 동정되었다. 당 분해능의 차이에 따라 분류한 결과는 Table 3 과 같다. 분리한 61 주는 11 개의 생물형으로 분류되었으며 이 중에서 lactose, trehalose, raffinose, starch, glycogen 분해능 이 있는 균주가 19주로 가장 많았으며, 모든 균주가 lactose 분해능이 있으나 mannitol과 sorbitol에 대해서 공시균주 중 각각 1 주 만이 분해능이 인정되었다.

61주의 S. suis에 대하여 PCR을 이용한 16S-rRNA 유전자부 위를 증폭한 결과는 Fig. 1 과 같다. PCR 후 증폭산물을 젤 상에 서 전기영동하여 자외선 조사하여 확인한 결과 $304 \mathrm{bp}$ 에서 $\mathrm{DNA}$ 분절이 검출되었다.

\section{항균제 감수성 시험}

디스크확산법에 의한 항생제 감수성 시험 결과는 Table 4 와 같다. Penicillin, ampicillin, amoxacillin/clablanic acid에 각 각 $55.7 \%, 80.3 \%, 98.4 \%$ 의 감수성을 나타내었으며, cepha-

Table 1. Property of S. suis isolated in this study

\begin{tabular}{ccccccccc}
\hline \multirow{2}{*}{ Year } & \multirow{2}{*}{ No. of farm } & \multirow{2}{*}{ No. of isolates } & \multicolumn{5}{c}{ Organ isolated } \\
\cline { 4 - 9 } & & 7 & Brain & Lung & Liver & Spleen & Joint & Kidney \\
\hline 2004 & 6 & 22 & 2 & 1 & - & 1 & 2 & 1 \\
2005 & 14 & 15 & 3 & 7 & 1 & - & 4 & - \\
2006 & 10 & 5 & 1 & 4 & - & - & - & - \\
2007 & 5 & 12 & 7 & 5 & & & - \\
2009 & 5 & 61 & 24 & 23 & 3 & 4 & 6 \\
\hline Total & 40 & & & & & & & - \\
\hline
\end{tabular}

Table 2. Biochemical properties of 61 S. suis isolated

\begin{tabular}{|c|c|c|c|}
\hline \multicolumn{2}{|c|}{ Test or substrates } & \multicolumn{2}{|c|}{ No. of positive isolates (\%) } \\
\hline Pyruvate (VP) & & 0 & $(-)$ \\
\hline Hippurate & & 61 & (100) \\
\hline Esculin & & 61 & (100) \\
\hline Pyrrolidonyl 2-naphthylamide & & 61 & (100) \\
\hline$\alpha$-D-galactopyranoside & & 61 & $(100)$ \\
\hline$\beta$-D-glucuronate & & 61 & $(100)$ \\
\hline$\beta$-D-galactopyranoside & & 61 & (100) \\
\hline 2-naphthyl phosphate & & 61 & (100) \\
\hline L-leucine-2-naphthylamide & & 61 & (100) \\
\hline Decarboxylation of arginine & & 61 & (100) \\
\hline$\beta$-hemolysis & & 0 & $(-)$ \\
\hline \multirow[t]{10}{*}{ Acidification of } & Ribose (RIB) & 0 & $(-)$ \\
\hline & L-arabinose (ARA) & 0 & $(-)$ \\
\hline & Mannitol (MAN) & 1 & $(1.6)$ \\
\hline & Sorbitol (SOR) & 1 & $(1.6)$ \\
\hline & Lactose (LAC) & 61 & $(100)$ \\
\hline & Trehalose (TRE) & 58 & $(95.1)$ \\
\hline & Inulin (INU) & 39 & $(63.9)$ \\
\hline & Raffinose (RAF) & 42 & $(68.9)$ \\
\hline & Starch (AMD) & 59 & $(96.7)$ \\
\hline & Glycogen (GLYG) & 52 & $(85.2)$ \\
\hline
\end{tabular}


Table 3. Phenotype of $S$. suis isolated by biochemical properties

\begin{tabular}{lcc}
\hline \multicolumn{1}{c}{$\begin{array}{c}\text { Positive acidification of } \\
\text { carbohydrate }\end{array}$} & Phenotype & $\begin{array}{c}\text { No. of } \\
\text { isolates }\end{array}$ \\
\hline LAC-TRE-AMD-GLYG & 1413 & 2 \\
LAC-INU-AMD-GLYG & 1423 & 2 \\
LAC-TRE-INU-AMD & 1431 & 3 \\
LAC-TRE-INU-GLYG & 1432 & 1 \\
LAC-TRE-INU-AMD-GLYG & 1433 & 11 \\
LAC-TRE-RAF-AMD-GLYG & 1453 & 19 \\
LAC-TRE-INU-RAF-AMD & 1471 & 6 \\
LAC-TRE-INU-RAF-GLYG & 1472 & 1 \\
LAC-TRE-INU-RAF-AMD-GLYG & 1473 & 14 \\
MAN-LAC-INU-RAF-AMD-GLYG & 1563 & 1 \\
SOR-LAC-TRE-RAF-AMD-GLYG & 1653 & 1 \\
\hline \multicolumn{1}{c}{ Total } & 11 type & 61 \\
\hline
\end{tabular}

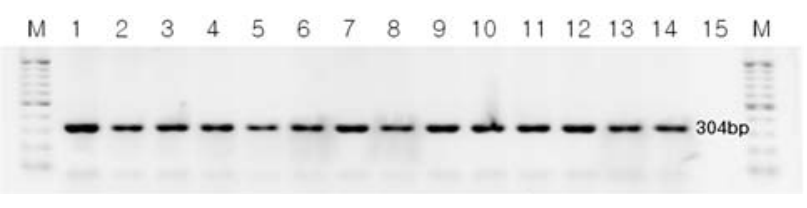

Fig. 1. Specific amplification of PCR for identification of S. suis. Lane M: 100bp DNA size marker, Lane 1-14: S. suis isolates, Lane 15: Negative DNA control.

Table 4. Antimicrobial susceptibility test of $61 \mathrm{~S}$. suis isolated

\begin{tabular}{lcc}
\hline \multicolumn{1}{c}{ Antimicrobial drugs } & Susceptible & $(\%)$ \\
\hline Penicillin & 34 & 55.7 \\
Ampicillin & 49 & 80.3 \\
Amoxycillin/clavulanic acid & 60 & 98.4 \\
Cephalothin & 55 & 90.2 \\
Cefoperazone & 60 & 98.4 \\
Cefepime & 33 & 54.1 \\
Ceftiofur & 45 & 73.8 \\
Norfloxacin & 32 & 52.5 \\
Enrofloxacin & 30 & 49.2 \\
Ciprofloxacin & 39 & 63.9 \\
Gentamicin & 18 & 29.5 \\
Kanamycin & 0 & - \\
Amikacin & 0 & - \\
Neomycin & 0 & - \\
Streptomycin & 0 & - \\
Spectinomycin & 35 & 57.4 \\
Erythromycin & 6 & 9.8 \\
Clindamycin & 0 & - \\
Chloramphenicol & 32 & 52.5 \\
Florfenicol & 54 & 88.5 \\
Tilmicosin & 2 & 3.3 \\
Trimethoprim/sulfamethoxazole & 16 & 26.2 \\
Doxycycline & 10 & 16.4 \\
Tetracycline & 1 & 1.6 \\
\hline
\end{tabular}

losporin 계열 중에서는 cefopherazone에 60주(98.4\%)가 감수 성을 나타내었고, quinolone 계열 항균제인 norfloxacin, ciprofloxacin, enrofloxacin에는 각각 32주(52.5\%), 39주(63.9\%), 30 주(49.2\%)가 감수성을 나타내었다. Aminoglycoside 계열 중에서는 spectinomycin에 35주(57.4\%)가 감수성이 있는 것으 로 조사되었고 kanamycin, amikacin, neomycin, streptomy$\operatorname{cin}$ 에는 모든 균주가 내성이 있는 것으로 나타났다. Tetracycline 계열인 doxycycline과 tetracycline에는 각각 10 주와 1 주만이 감수성을 나타내었다.

\section{고 찰}

S. suis는 양돈산업과 관련된 대부분의 국가에서 발생하는 중요한 세균성 질병의 원인체이며 주로 3 주에서 12 주령 사이 에 감염되어 뇌막염, 관절염, 심내막염, 패혈증, 폐렴, 급사 등 의 다양한 증상을 나타낸다 $[25,33,45]$. 최근까지 35 종의 혈청형 으로 분류되며 생화학적 성상이 다양하여 기존의 혈청형에 따른 균의 분류에 많은 제약이 따른다[5,31]. 본 실험에서는 상용화 균동정 킷트인 API $20 \mathrm{STREP}$ 과 특이 유전자부위인 16S-rRNA에 대한 PCR을 실시하여 균을 동정하고 당 및 starch의 분해능의 차이에 따른 phenotype을 조사한 바 11개 의 phenotype으로 나누어졌으며 이 중에서 lactose, trehalose, raffinose, glycogen 및 starch 분해능을 가진 균주가 19주로 가장 많은 것으로 조사되었다. 구 등[24]은 도축돈의 폐 병변에 서 분리한 S. suis 50 주를 대상으로 생화학적 성상을 조사한 결과 모든 균주가 ribose(-), lactose $(+)$ 이었으며, trehalose (93.3\%), inulin (93.3\%), raffinose (93.3\%)라고 하였으나 본 실 험에서는 inulin $(63.9 \%)$ 과 raffinose $(68.9 \%)$ 분해능이 다소 낮게 나타났다. 이러한 성적은 소 등[42]이 도축돈에서 분리한 S. suis의 생화학적 성상시험 결과와도 다소 차이가 인정되었 으나 Han 등[13]이 도축돈에서 분리한 55주의 S. suis를 대상으 로 조사한 lactose $(96 \%)$, trehalose $(96 \%)$, sorbitol $(4 \%)$ 의 성적 과는 유사하였으며 mannitol $(24 \%)$ 의 성적은 다소 차이가 있 는 것으로 나타났다.

전 세계적으로 S. suis는 혈청형 2형이 주로 감염되어 발생 하며 그 외 다른 혈청형의 분포에 대한 조사도 많이 이루어졌 고[51], 추가로 병원성 인자인 MRP와 $\mathrm{EF}$ 에 대한 유전자 유무 를 검출하여 병원성유무를 조사하기도 하나 일부 연구에서 환돈 유래 분리주의 경우에도 $\mathrm{MRP}$ 와 $\mathrm{EF}$ 의 불검출 균주가 다 수 있는 것으로 조사되었다[10,35,52]. 본 연구에서는 환돈 유 래 분리주에서 $\mathrm{MRP}$ 와 $\mathrm{EF}$ 에 대한 유무를 조사하지는 않아 추 후에 분리 장기에 따른 병원성 인자의 유무 등을 조사하여야 할 것으로 생각된다.

Aarestrup 등[1]은 1995년에서 1996년 사이 덴마크에서 병 성감정 의뢰된 돼지가검물에서 분리된 S. suis를 대상으로 항 균제 감수성 시험을 실시하여 대부분의 균주가 ampicillin 등 
8종의 항균제에 감수성이 있으나 일부 균주가 tetracycline, lincomycin 및 spiramycin에는 저항성이 있다고 보고하면서 혈청형별로 감수성 약제에 차이가 있으며 분리 연도별 연쇄상 구균의 혈청형에 다소 변화가 있다고 보고한 바 있다. 본 실험 에서는 penicillin 계열과 cephalosoporin 계열 항균제에는 대 부분 높은 감수성을 나타내었으나 tetracycline 계열과 aminoglycocide 계열에는 대부분의 균주가 내성을 가지는 것으로 나타났고 quinolone 계열의 항균제인 norploxacin, enrofloxacin, ciprofloxacin에도 내성을 나타내는 균주가 다수 조 사되어 Wisselink 등[53]과 Zhu 등[55]의 다른 연구자들의 항 균제 감수성 시험과 유사한 결과를 나타내었다. Marie 등[26] 은 프랑스에서 분리한 사람 및 돼지 유래 S. suis의 항균제 감수 성 결과를 발표하면서 $\beta$-lactam 계열에 대한 치료목적으로 우 선 사용을 언급한 바 있다. 본 실험에서도 cephalothin, cefoperazone, cefepime 및 ceftiofur에 대한 감수성 조사 결과 cefepime을 제외하고 대부분 높은 감수성을 가지는 것으로 조사 되었다. Reams 등[32]은 1985년부터 1989년 사이에 분리한 256주의 S. suis를 대상으로 혈청형별 항균제 감수성 양상을 조사하여 보고하면서 다소 혈청형별 차이는 있으나 tetracycline을 제외한 trimethoprim/sulfamethoxazole 및 ampicillin 등 8종의 항균제에 대하여 감수성이 있다고 보고하였으나 본 실험에서는 trimethoprim/sulfamethoxazole에 대하여 16 주 (26.2\%)만이 감수성 있는 것으로 조사되어 설파제에 대한 내 성율이 높은 것으로 조사되었고, 특히 neomycin의 경우 전 균주가 내성을 가지는 것으로 조사되어 많은 차이가 나타났 다. 이러한 결과는 광범위한 항생제 오,남용에 의한 상재균인 S. suis의 내성획득과도 관련이 있을 것으로 생각되며 치료 목 적 및 예방적 항균제의 사용시에 투약제의 선정에 더욱더 신 중을 기울여야 할 것으로 생각된다. 또한 S. suis가 혈청형별에 따른 항균제의 감수성 차이가 여러 연구자에 의해 보고된 바 있으므로 PCR 등을 이용한 S. suis의 혈청형별에 대한 연구 및 개발이 지속적으로 이루어져 신속한 혈청형 동정이 약제 선정과 병행되어야 할 것으로 생각된다.

\section{References}

1. Aarestrup, F. M., S. E. Jorsal, and N. E. Jensen. 1998. Serological characterization and antimicrobial susceptibility of Streptococcus suis isolates from diagnostic samplees in Denmark during 1995 and 1996. Vet. Microbiol. 60, 59-66.

2. Bungener, W. and R. Bialek. 1989. Fatal Streptococcus suis septicemia in an abattoir worker. Eur. J. Clin. Microbiol. Infect. Dis. 8, 306-308.

3. Clifton-Hadley, F. A., M. R. Enright, and T. J. Alexander. 1986. Survival of Streptococcus suis type 2 in pig carcases. Vet. Rec. 118, 275.

4. Clinical and laboratory standards institute. 2009. Performance standards for antimicrobial disk susceptibility test; Approved standard, 10th eds. 29, M02-A10.

5. Devriese, L. A., K. Ceyssens, J. Hommez, R. Kilpper-Bälz, and K. H. Schleifer. 1991. Characteristics of different Streptococcus suis ecovars and description of a simplified identification method. Vet. Microbiol. 26, 141-150.

6. de Moor. C. E. 1963. Septicemic infections in pigs caused by haemolytic streptococci of new Lancefield groups designated R, S and T. Antonie van Leeuwenhoek. 29, 272-280.

7. Dupas, D., M. Vignon, and C. Géraut. 1992. Streptococcus suis meningitis. A severe noncompensated occupational disease. J. Occup. Med. 34, 1102-1105.

8. Galina, L., J. E. Collins, and C. Pijoan. 1992. Porcine Streptococcus suis in Minnesota. J. Vet. Diagn. Invest. 4, 195-196.

9. Gottschalk, M., R. Higgins, M. Jacques, K. R. Mittal, and J. Henrichsen. 1989. Description of 14 new capsular types of Streptococcus suis. J. Clin. Microbiol. 27, 2633-2636.

10. Gottschalk, M., A. Lebrun, H. Wisselink, J. D. Dubreuil, H. Smith, and U. Vecht. 1998. Production of virulence-related proteins by Canadian strains of Streptococcus suis capsular type 2. Can. J. Vet. Res. 62, 75-79.

11. Gottschalk, M. G., S. Lacouture, and J. D. Dubreuil. 1995. Characterization of Streptococcus suis capsular type 2 haemolysin. Microbiology 141, 189-195.

12. Gottschalk, M., S. Petitbois, R. Higgins, and M. Jacques. 1991. Adherence of Streptococcus suis capsular type 2 to porcine lung sections. Can. J. Vet. Res. 55, 302-304.

13. Han, D. U., C. S. Choi, H. J. Ham, J. H. Jung, W. S. Cho, J. H. Kim, R. Higgin, and C. H. Chae. 2001. Prevalence, capsular type and antimicrobial susceptibility of Streptococcus suis isolated from slaughter pigs in Korea. Can. J. Vet. Res. 65, 151-155.

14. Hantson, P., M. C. Vekemans, P. Gautier, P. Mahieu, C. J. Sindic, J. M. Guerit, G. Wauters, and M. Nannan. 1991. Fatal Streptococcus suis meningitis in man. Acta. Neurol. Belg. 91, 165-168.

15. Higgins, R. and M. Gottschalk. 1990. Review article: An update on Streptococcus suis identification. J. Vet. Diagn. Invest. 2, 249-252.

16. Higgins, R. and M. Gottschalk. 1996. Distribution of Streptococcus suis capsular types in 1995. Can. Vet. J. 37, 242.

17. Higgins, R., M. Gottschalk, M. Boudreau, A. Lebrun, and J. Henrichsen. 1995. Description of six new capsular types (29-34) of Streptococcus suis. J. Vet. Diagn. Invest. 7, 405-406.

18. Hong, T., J. Ndamukong, W. Millett, A. Kish, K. K. Win, and Y. J. Choi. 1996. Direct application of Etest to gram-positive cocci from blood cultures: quick and reliable minimum inhibitory concentration data. Diagn. Microbiol. Infect. Dis. 25, 21-25.

19. Hommez, J., L. A. Devriese, J. Henrichsen, and F. Castryck. 1986. Identification and characterization of Streptococcus suis. Vet. Microbiol. 11, 349-355.

20. Jansen, E. J. and C. A. van Dorssen. 1951. Meningoencephalitis bij varkens door streptococcen. Tijdschr. Diergeneeskd. 76, 815-832.

21. Jung, B. Y. S. C. Jung, J. Y. Kim, Y. H. Park, and B. H. 
Kim. 1998. Polymerase chain reaction for a rapid and specific identification of Streptococcus suis. Korean J. Vet. 38, 771-776.

22. Kataoka, Y., C. Sugimoto, M. Nakazawa, T. Morozumi, and M. Kashiwazaki. 1993. The epidemiological studies of Streptococcus suis infections in Japan from 1987 to 1991. J. Vet. Med. Sci. 55, 623-626.

23. Kay, R., A. F. Cheng, and C. Y. Tse. 1995. Streptococcus suis infection in Hong Kong. Q.J.M. 88, 39-47.

24. Koo, K. M., J. H. Lim, and H. B. Koh. 2002. The detection of Streptococcus suis serotype $1(+14), 2(+1 / 2), 7$ and 9 from pneumonic lungs in slaughtered pigs by a multiplex PCR. Korean J. Vet. 42, 495-504.

25. Lamont, M. H., P. T. Edward, and R. S. Windsor. 1980. Streptococcal meningitis in pigs: Results of a five-year survey. Vet. Rec. 107, 467-469.

26. Marie, J., H. Morvan, F. Berthelot-Hèrault, P. Sanders, L. Kempf, A. V. Gautier-Bouchardon, E. Jouy, and M. Kobisch. 2002. Antimicrobial susceptibility of Streptococcus suis isolated from swine in France and from humans in different countries between 1996 and 2000. J. Antimicrob. Chemother. 50, 201-209.

27. Marois, C., S. Bougeard, M. Gottschalk, and M. Kobisch. 2004. Multiplex PCR assay for detection of Streptococcus suis species and serotypes 2 and $1 / 2$ in tonsils of live and dead pigs. J. Clin. Microbiol. 42, 3169-3175.

28. Mogollon, J. D., C. Pijoan, M. P. Murtaugh, J. E. Collins, and P. P. Cleary. 1991. Identification of epidemic strains of Streptococcus suis by genomic fingerprinting. J. Clin. Microbiol. 29, 782-787.

29. Peetermans, W. E., B. G. Moffie, and J. Thompson. 1989. Bacterial endocarditis caused by Streptococcus suis type 2 . J. Infect. Dis. 159, 595-596.

30. Perch, B., K. B. Pedersen, and J. Henrichsen. 1983. Serology of capsulated streptococci pathogenic for pigs: six new serotypes of Streptococcus suis. J. Clin. Microbiol. 17, 993-996.

31. Prieto, C., F. J. García, P. Suárez, M. Imáz, and J. M. Castro. 1994. Biochemical traits and antimicrobial susceptibility of Streptococcus suis isolated from slaughtered pigs. Zentralbl. Veterinarmed B. 41, 608-617.

32. Reams, R. Y., L. T. Glickman, D. D. Harrington, T. L. Bowersock, and H. L. Thacker. 1993. Streptococcus suis infection in swine: a retrospective study of 256 case. Part I . Epidemiologic factors and antibiotic susceptibility patterns. J. Vet. Diagn. Invest. 5, 363-367.

33. Reams, R. Y., L. T. Glickman, D. D. Harrington, H. L. Thacker, and T. L. Bowersock. 1994. Streptococcus suis infection in swine: a retrospective study of 256 cases. Part II. Clinical signs, gross and microscopic lesions, and coexisting microorganisms. J. Vet. Diagn. Invest. 6, 326-334.

34. Reams, R. Y., D. D. Harrington, L. T. Glickman, H. L. Thacker, and T. L. Bowersock. 1996. Multiple serotypes and strains of Streptococcus suis in naturally infected swine herds. J. Vet. Diagn. Invest. 8, 119-121.

35. Salasia, S. I. and C. Lämmler. 1995. Distribution of serotype, virulence markers and further characteristics of Streptococcus suis isolates from pigs. Zentralbl Veterinarmed B. 42, 78-83.

36. Sanford, S. E. and M. E. Tilker. 1982. Streptococcus suis type II-associated diseases in swine: observations of a one-year study. J. Am. Vet. Med. Assoc. 181, 673-676.

37. Seok, H. B., K. H. Lee, and J. G. Yeh. 1992. Studies on Streptococcal Infection in Young Pigs 2 . Prevalance of Streptococcus suis Type 2 in Clinically Healthy Pig and Antibiotics Susceptibility Test of the Isolates. Korean J. Vet. Publ. Hlth. 16, 169-178.

38. Sihvonen, L., D. N. Kurl, and J. Henrichsen. 1988. Streptococcus suis isolated from pigs in Finland. Acta. Vet. Scand. 29, 9-13.

39. Sihvonen, L., D. N. Kurl, and P. Salmela. 1986. Infection with Streptococcus suis serotypes 1 and 2 in the same diseased pig. Acta. Vet. Scand. 27, 626-628.

40. Smith, D. J., B. Shoushtari, R. L. Heschel, W. F. King, and M. A. Taubman. 1997. Immunogenicity and protective immunity induced by synthetic peptides associated with a catalytic subdomain of mutans group streptococcal glucosyltransferase. Infect. Immun. 65, 4424-4430.

41. Smith, H. E., V. Veenbergen, J. van der Velde, M. Damman, H. J. Wisselink, and M. A. Smits. 1999. The cps genes of Streptococcus suis serotypes 1, 2, and 9: Development of rapid serotype-specific PCR assays. J. Clin. Microbiol. 37, 31463152.

42. So, S. H., B. H. Kim, and G. J. Cho. 1995. Biochemical characteristics and capsular serotypes of Streptococcus suis isolated from pneumonic lungs of slaughter pigs. Korean. J. Vet. 35, 297-306.

43. Straw. B. E., S. D'Allaire, W. L. Mengeling, and D. J. Taylor. 1999. Diseases of swine, 8th Ed. Iowa State University Press. Ames, Iowa. 563-578.

44. Tarradas, C., A. Arenas, A. Maldonado, I. Luque, A. Miranda, and A. Perea. 1994. Identification of Streptococcus suis isolated from swine: proposal for biochemical parameters. J. Clin. Microbiol. 32, 578-580.

45. Vecht, U., L. A. van Leengoed, and E. R. Verheijen. 1985. Streptococcus suis infections in pigs in the Netherlands (Part I). Vet. Q. 7, 315-321.

46. Vecht, U., H. J. Wisselink, M. L. Jellema, and H. E. Smith. 1991. Identification of two proteins associated with virulence of Streptococcus suis type 2. Infect Immun. 59, 3156-3162.

47. Vecht, U., H. J. Wisselink, N. Stockhofe-Zurwieden, and H. E. Smith. 1996. Characterization of virulence of the Streptococcus suis serotype 2 reference strain Henrichsen S 735 in newborn gnotobiotic pigs. Vet. Microbiol. 51, 125-136.

48. Vecht, U., L. A. van Leengoed, and E. R. Verheijen. 1985. Streptococcus suis infections in pigs in the Netherlands (Part I). Vet. Q. 7, 315-321.

49. Windsor, R. S. and S. D. Elliott. 1975. Streptococcal infection in young pigs. IV. An outbreak of streptococcal meningitis in weaned pigs. J. Hyg. (Lond). 75, 69-78.

50. Wisselink, H. J., J. J. Joosten, and H. E. Smith. 2002. Multiplex PCR assays for simultaneous detection of six major serotypes and two virulence-associated phenotypes of Streptococcus suis in tonsillar specimens from pigs. J. Clin. 
Microbiol. 40, 2922-2929.

51. Wisselink, H. J., F. H. Reek, U. Vecht, N. StockhofeZurwieden, M. A. Smits, and H. H. Smith. 1999. Detection of virulent strains of Streptococcus suis type 2 and highly virulent strains of Streptococcus suis type 1 in tonsillar specimens of pigs by PCR. Vet. Microbiol. 67, 143-157.

52. Wisselink, H. J., H. E. Smith, N. Stockhofe-Zurwieden, K. Peperkamp, and U. Vecht. 2000. Distribution of capsular type and production of muramidase-released protein(MRP) and extracellular factor(EF) of Streptococcus suis strains isolated from diseased pigs in seven European countries. Vet. Microbiol. 74, 237-248.
53. Wisselink, H. J., K. T. Veldman, C. Van den Eede, S. A. Salmon, and D. J. Mevius. 2006. Quantitative susceptibility of Streptococcus suis strains isolated from diseased pigs in seven European countries to antimicrobial agents licensed in veterinary medicine. Vet. Microbiol. 113, 73-82.

54. Yoon, S. J. and H. B. Koh. 1997. Studies on the Streptococcus suis isolated from slaughtered pigs. Korean J. Vet. Serv. 20, 281-288.

55. Zhu, H., J. He, H. B. Jing, Z. Q. Wang, and Q. Duan. 2006. Isolation and identification of Streptococcus suis serotype 2 from sick-pig samples of Sichuan province. Wei. Sheng. Wu. Хие. Вао. 46, 635-638.

\title{
초록 : 경북지방 환돈에서 분리한 Streptococcus suis의 생화학적 성상 및 약제감수성
}

\author{
최성균 · 김성국 · 김영환 · 최정혜 · 조민희 · 조길재 ${ }^{1 *}$ \\ (경상북도 가축위생시험소, ${ }^{1}$ 경북대학교 수의과대학)
}

Streptococcus suis는 사람과 돼지에서 다양한 감염을 유발하는 병원체이다. 2004년부터 2009년까지 경북지방 양돈장 에서 병성감정 의뢰한 돼지 가검물을 대상으로 S. suis를 분리하여 생화학적 성상, 약제감수성 시험 및 PCR을 이용한 동정을 실시한 결과는 다음과 같다. 40 개 농장에서 분리한 61주의 S. suis에 대하여 생화학적 성상시험 결과 모두 $S$. suis로 동정되었으며, VP 음성, hippurate, esculin, arginine decarboxylase 양성, lactose 분해능이 있는 것으로 나타났 다. Trehalose와 starch 분해능은 비교적 높게 나타넜으며 생화학적 성상에 따른 phenotype은 11형으로 나누어졌다. 항 생제 감수성 시험 결과 대부분의 균주가 amoxicillin/clavulanic acid, ampicillin, cephalothin, cefoperazone, florfenicol 에 높은 감수성을 나타내었지만 amikacin, kanamycin, neomycin, streptomycin, erythromycin, clindamycin, tetracycline에는 높은 내성을 나타내었다. 16S-rRNA 특이유전자 부위를 이용한 PCR 결과 공시균주 모두 $304 \mathrm{bp}$ 에서 증폭산 물이 관찰되었다. 이들 결과는 국내에서 사육되고 있는 돼지에서 S. suis 감염을 예방하는데 도움이 될 것으로 기대된다. 